\title{
Clinical and in Vitro Evidence against Placenta Infection at Term by Severe Acute Respiratory Syndrome Coronavirus 2
}

Arthur Colson, ${ }^{* \dagger \ddagger}$ Christophe L. Depoix, ${ }^{*}$ Géraldine Dessilly, Pamela Baldin, ${ }^{\llbracket}$ Olivier Danhaive, ${ }^{\S *}$ Corinne Hubinont, ${ }^{* \sharp}$ Pierre Sonveaux, ${ }^{\dagger}$ and Frédéric Debiève ${ }^{* \sharp}$

From the Poles of Obstetrics, ${ }^{*}$ Pharmacology and Therapeutics, ${ }^{\dagger}$ and Medical Microbiology, ${ }^{\S}$ Institute of Experimental and Clinical Research, Catholic University of Louvain, Brussels, Belgium; the Divisions of Obstetrics ${ }^{\ddagger}$ and Neonatology" and the Department of Pathology, "Saint-Luc University Hospital, Brussels, Belgium; and the Department of Pediatrics, ${ }^{* *}$ Benioff Children's Hospital, University of California, San Francisco, San Francisco, California

Accepted for publication

May 20, 2021.

Address correspondence to Arthur Colson, M.D., Institut de Recherche Expérimentale et Clinique, Université Catholique de Louvain, Ave. Hippocrate, 54, B1.55.03, Brussels, Belgium. E-mail: arthur.colson@ uclouvain.be.

\begin{abstract}
Despite occasional reports of vertical transmission of severe acute respiratory syndrome coronavirus 2 (SARS-CoV-2) during pregnancy, the question of placental infection and its consequences for the newborn remain unanswered. Herein, we analyzed the placentas of 31 coronavirus disease 2019-positive mothers by reverse transcriptase PCR, immunohistochemistry, and in situ hybridization. Only one case of placental infection was detected, which was associated with intrauterine demise of the fetus. Differentiated primary trophoblasts were then isolated from nonpathologic human placentas at term, differentiated, and exposed to SARS-CoV-2 virions. Unlike for positive control cells Vero E6, the virus inside cytotrophoblasts and syncytiotrophoblasts or in the supernatant 4 days after infection was undetectable. As a mechanism of defense, we hypothesized that trophoblasts at term do not express angiotensin-converting enzyme 2 and transmembrane protease serine 2 (TMPRSS2), the two main host membrane receptors for SARS-CoV-2 entry. The quantification of these proteins in the placenta during pregnancy confirmed the absence of TMPRSS2 at the surface of the syncytium. Surprisingly, a transiently induced experimental expression of TMPRSS2 did not allow the entry or replication of the virus in differentiated trophoblasts. Altogether, these results underline that trophoblasts are not likely to be infected by SARS-CoV-2 at term, but raise concern about preterm infection. (Am J Pathol 2021, 191: 1610-1623; https://doi.org/10.1016/ j.ajpath.2021.05.009)
\end{abstract}

Within a year, the coronavirus disease 2019 (COVID-19) pandemic has become a worldwide health and social crisis, deeply affecting human lives and questioning the future of humankind. Although our knowledge about COVID-19 has exponentially increased, many questions remain to be answered. Pregnant women are particularly vulnerable to respiratory infectious diseases because of the remodeling of their immune and cardiovascular systems. ${ }^{1}$ Initially, it was shown that pregnant women infected by severe acute respiratory syndrome coronavirus 2 (SARS-CoV-2) are more likely to require intensive care treatment, and their pregnancies are associated with increased incidence of miscarriage, preterm birth, preeclampsia, cesarean delivery, and perinatal deaths. ${ }^{2}$ The meta-analyses are less clear, as maternal COVID-19 was not necessarily associated with adverse pregnancy and neonatal complications. $^{3-6}$

Maternofetal transmission of SARS-CoV-2 remains a matter of investigation because few neonates have shown evidence of contamination following maternal infection. ${ }^{7}$ Direct involvement of the placenta is rare, and robust virological evidence, whether by reverse transcriptase PCR, immunohistochemistry (IHC), or in situ hybridization (ISH),

\footnotetext{
Supported by the Belgian Fund for Scientific Research (F.R.S.-FNRS) under grant 40002773, the Fetus for Life Charity, and the Louvain Foundation. A.C. is a FRIA PhD Fellow of F.R.S.-FNRS. P.S. is a Research Director of the F.R.S.-FNRS.

A.C. and C.L.D. contributed equally to this work.

Disclosures: None declared.
} 
Table 1 Antibodies Used for WB Analysis, IHC, and IF

\begin{tabular}{llll}
\hline Target & Source & Reference & Use and technical notes \\
\hline SARS-CoV-2 spike & Sino Biological, Beijing, China & 40150-V08B1 & IHC: 1:2000, citrate buffer (pH 5.7) \\
SARS-CoV-2 spike & Genetex, Irvine, CA & GTX632604 & IHC: 1:200, citrate buffer (pH 5.7) \\
SARS-CoV-2 nucleocapsid & Invitrogen, Thermo Fisher Scientific, & MA17404 & IHC: 1:100, TE buffer (pH 9) \\
& $\quad$ Waltham, MA & & IF: 1:100, methanol \\
Desmoplakin I + II & Abcam, Cambridge, UK & Ab16434 & IF: 1:200, methanol \\
Cytokeratin 7 & Cell Signaling Technology, Danvers, MA & 4465 & IF: 1:100, methanol \\
Alexa Fluor 488 anti-mouse & Cell Signaling Technology & $4408 S$ & IF: secondary antibody, 1:500 \\
Alexa Fluor 555 anti-rabbit & Cell Signaling Technology & 4413 & IF: secondary antibody, 1:500 \\
Human ACE2 & Sigma-Aldrich, St. Louis, M0 & AMAb91268 & IHC: 1:200, citrate buffer (pH 5.7) \\
Human ACE2 & Novus Biologicals, Centennial, C0 & AF933 & WB analysis: $1: 400$, blocking with milk 5\% \\
Human TMPRSS2 & Sigma-Aldrich & HPA035787 & IHC: 1:300, citrate buffer (pH 5.7) \\
& & & IF: 1:200, PFA
\end{tabular}

ACE2, angiotensin-converting enzyme 2; IF, immunofluorescence; IHC, immunohistochemistry; PFA, paraformaldehyde; TMPRSS2, transmembrane protease serine 2; WB, Western blot.

is often missing in the reported cases..$^{8-10}$ However, the debate was revived with the documentation of intrauterine transmission and placental infection. ${ }^{11-13}$ As SARS-CoV-2 has been detected in the blood of severely ill patients, circulating viral particles are likely to interact with the maternofetal interface. ${ }^{14}$ Especially, the mononuclear villous cytotrophoblasts (CTBs) fuse and differentiate into syncytiotrophoblasts (STBs), which are in direct contact with maternal blood. ${ }^{15}$

SARS-CoV-2 is a $\beta$-coronavirus composed of spike, envelope, membrane, and nucleocapsid proteins encompassing a single-stranded RNA genome of 29,891 nucleotides. $^{16}$ Its infectivity depends primarily on the expression, localization, and structure of the transmembrane proteins angiotensin-converting enzyme 2 (ACE2) and the transmembrane protease serine 2 (TMPRSS2). ${ }^{17}$ To infect human cells, SARS-CoV-2 engages ACE2 as the entry receptor and employs TMPRSS2 for spike protein priming, allowing the fusion of viral and cellular membranes. ACE2 and TMPRSS2 expression at the surface of cells is therefore considered as a biological indicator of their susceptibility for SARS-CoV-2 infection. ACE2 and TMPRSS2 were detected in the human placenta throughout pregnancy, but their co-expression by syncytiotrophoblasts remains controversial. ${ }^{18-20}$

This study aimed to explore the probability of vertical transmission through placental infection by SARS-CoV-2.
In a cohort of 31 pregnant women with maternal COVID19, the viral expression and clinical/immune responses of the mother-infant dyad to SARS-CoV-2 infection were characterized. Then, using a combination of histologic observations and culture of human primary trophoblasts, placental suscptibility to infection was tested and potential mechanisms of resistance to the virus entry were investigated.

\section{Materials and Methods}

\section{Clinical Study and Sample Collection}

This study was conducted with the approval of the Ethical Committee of the Catholic University of Louvain (approval number 2020/18AVR/228) in Saint-Luc University Hospital (Brussels, Belgium). Between April 1, 2020, and December 1, 2020, 31 pregnant women who were tested positive for SARS-CoV-2 by reverse transcriptase PCR during their pregnancy were included after informed consent. After delivery, one piece of the placenta was quickly stored in RNAlater (Invitrogen, Thermo Fisher Scientific, Waltham, MA) at $-80^{\circ} \mathrm{C}$. Placental samples were fixed in formalin and paraffin embedded for histologic analyses. For a subset of patients, additional samples were collected during their hospitalization for delivery: maternal plasma, vaginal swab, rectal swab,

Table 2 Primers Used for Quantitative Real-Time PCR

\begin{tabular}{|c|c|c|}
\hline Gene & Forward primer & Reverse primer \\
\hline$C G B$ & 5'-GCTACTGCCCCACCATGACC-3' & 5'-ATGGACTCGAAGCGCACATC-3' \\
\hline ACE2 & 5'-CGAGTGGCTAATTTGAAACCAAGAA-3' & $5^{\prime}$-ATTGATACGGCTCCGGGACA-3' \\
\hline SDHA & 5'-TGGGAACAAGAGGGCATCTG-3' & $5^{\prime}$-CCACCACTGCATCAAATTCATG-3' \\
\hline$T B P$ & $5^{\prime}$-GAACATCATGGATCAGAACAACA-3' & 5'-ATAGGGATTCCGGGAGTCAT-3' \\
\hline
\end{tabular}


Table 3 Maternal and Fetal Characteristics

\begin{tabular}{|c|c|}
\hline Characteristic & Value \\
\hline \multicolumn{2}{|l|}{ Mother } \\
\hline Age, years & $31(4.28)$ \\
\hline $\mathrm{BMI}, \mathrm{kg} / \mathrm{m}^{2}$ & $25.18(5.53)$ \\
\hline$>30 \mathrm{~kg} / \mathrm{m}^{2}, \%$ & 12.90 \\
\hline \multicolumn{2}{|l|}{ Ethnic group, \% } \\
\hline White & 48.39 \\
\hline Black & 22.58 \\
\hline Asian & 0 \\
\hline Other & 29.03 \\
\hline Primiparity, $\%$ & 41.94 \\
\hline \multicolumn{2}{|l|}{ Pregnancy and labor } \\
\hline \multicolumn{2}{|l|}{ Complications, $\%$} \\
\hline PE & 6.45 \\
\hline Gestational diabetes & 9.68 \\
\hline Placental abruption & 3.23 \\
\hline \multicolumn{2}{|l|}{ Cesarean section, \% } \\
\hline Elective or breech & 35.48 \\
\hline Emergency (fetal distress) & 12.9 \\
\hline \multicolumn{2}{|l|}{ Fetus } \\
\hline \multicolumn{2}{|l|}{ Weight } \\
\hline Mean, g & $3190(851.72)$ \\
\hline$<5$ th percentile, $\%$ & 12.90 \\
\hline Sex, $\%$ male & 48.39 \\
\hline \multicolumn{2}{|l|}{ Gestational age } \\
\hline Mean, weeks.day & 38.1 \\
\hline$<34$ Weeks, \% & 6.45 \\
\hline \multicolumn{2}{|l|}{ Neonatal outcomes, \% } \\
\hline Apgar at 5 minutes $<8$ & 6.45 \\
\hline Neonatal infection & 12.90 \\
\hline Intrauterine death & 3.23 \\
\hline Malformations & 3.23 \\
\hline \multicolumn{2}{|l|}{ COVID-19 history } \\
\hline \multicolumn{2}{|l|}{ Positive test, $\%$} \\
\hline Before 30 weeks & 12.90 \\
\hline$<10$ Days before delivery & 70.97 \\
\hline \multicolumn{2}{|l|}{ Symptoms, \% } \\
\hline Asymptomatic & 61.29 \\
\hline Mild (fatigue, anosmia, or ageusia) & 19.35 \\
\hline Moderate (fever, cough, or dyspnea) & 16.13 \\
\hline Hospitalization for respiratory distress & 3.23 \\
\hline
\end{tabular}

Data are presented as means (SD), unless otherwise indicated. $\mathrm{BMI}$, body mass index; $\mathrm{PE}$, preeclampsia.

maternal urine, maternal milk, plasma from cord blood, nasopharyngeal neonatal swab, and fetal urine.

\section{Detection of SARS-CoV-2 by Reverse Transcriptase PCR}

Detection of SARS-CoV-2 RNA was performed using reverse transcriptase PCR, according to the protocol of the Pasteur Institute (Paris, France). ${ }^{21}$ Briefly, viral RNA was extracted from liquid samples using QIAamp MinElute Virus Spin Kit (Qiagen, Hilden, Germany) and from tissue samples with PureLink RNA Mini Kit (Invitrogen, Thermo Fisher Scientific). Extracted RNA was eluted in $30 \mu \mathrm{L}$ of elution buffer. The PCR amplification regions (positions according to SARS-CoV, NC_004718; https://www.ncbi. nlm.nih.gov/nuccore/nc_004718.3, last accessed August 4, 2021) were nCoV_IP2/12621-12727 and nCoV_IP4/ 14010-14116. A $25-\mu \mathrm{L}$ reaction containing $5 \mu \mathrm{L}$ of extracted RNA and $0.4 \mu \mathrm{mol} / \mathrm{L}$ of specific primers [RdRp nCoV_IP2, 5'-ATGAGCTTAGTCCTGTTG-3' (forward) and $5^{\prime}$-CTCCCTTTGTTGTGTTGT- $3^{\prime}$ (reverse), AGATGTCTTGTGCTGCCGGTA [5']Hex [3']BHQ-1; RdRp_nCoV_IP4, 5'-GGTAACTGGTATGATTTCG-3' (forward) and 5'-CTGGTCAAGGTTAATATAGG-3' (reverse), TCATACAAACCACGCCAGG [5']Fam [3'] BHQ-1] was performed with Takyon One-Step ROX Probe $5 \times$ MasterMix dTTP blue (Eurogentec, Seraing, Belgium) and amplified on a StepOne Real-Time PCR System (Applied Biosystems, Thermo Fisher Scientific). In addition to unknown samples, each assay includes one negative control (water) and five positive controls consisting of in vitro synthesized RNA transcripts $\left(10^{7}, 10^{6}, 10^{5}, 10^{4}\right.$, and $10^{3}$ copies genome equivalent).

\section{Detection of Anti-SARS-CoV-2 Antibodies in Plasma}

The presence of antibodies in maternal and fetal plasma samples was investigated by using the Elecsys anti-SARSCoV-2 immunoassay (Roche, Mannheim, Germany), according to manufacturer's protocol. If the test was positive, the Ig class was determined by the MAGLUMI 2019-nCoV IgM/IgG assay (Snibe, Shenzhen, China). Results higher than one arbitrary unit per milliliter were considered to be significant.

\section{Detection of SARS-CoV-2 in Tissue Sections}

Three antibodies adapted for IHC were initially tested: two rabbit polyclonal antibodies directed against the spike protein and one mouse monoclonal antibody raised against the nucleocapsid of the virus (Table 1). Positive control slides consisted of tissues that were tested positive by reverse transcriptase PCR: a lung autopsy from a COVID19-deceased patient and the preterm infected placenta. Negative controls were retrieved from 2017 samples: a normal lung biopsy (for diagnosis), a lung biopsy from acute respiratory distress syndrome (from nonvirological origin), and a term placenta from uncomplicated pregnancy (Supplemental Figures S1-S3).

COVID-19 immunostaining was confirmed with ISH by using the RNAscope 2.5 HD Assay-RED kit (Advanced Cell Diagnostics, Bio-Techne, Minneapolis, MN). A specific probe directed against nCoV2019-S-sense (catalog number 848561, NC_045512.2, https://www.ncbi.nlm.nih. gov/nuсcore/nc_045512.2, last accessed August 4, 2021) was used to detect viral RNA. ${ }^{22}$ The positive probe was directed against UBC (catalog number 310041, NM_021009, https://www.ncbi.nlm.nih.gov/nuccorel 1519312341, last accessed August 4, 2021), the gene 
Table 4 Detection of SARS-CoV-2 RNA in Various Biological Fluids and Quantification of Anti-SARS-CoV-2 Antibodies in Maternal and Fetal Plasma Samples

\begin{tabular}{|c|c|c|c|c|c|c|c|c|c|c|c|c|}
\hline Patient no. & $\begin{array}{l}\text { COVID-19 } \\
\text { positive } \\
<10 \text { days }\end{array}$ & $\begin{array}{l}\text { Maternal } \\
\text { plasma }\end{array}$ & $\begin{array}{l}\text { Fetal } \\
\text { plasma }\end{array}$ & $\begin{array}{l}\text { Vaginal } \\
\text { swab }\end{array}$ & $\begin{array}{l}\text { Rectal } \\
\text { swab }\end{array}$ & $\begin{array}{l}\text { Maternal } \\
\text { urine }\end{array}$ & $\begin{array}{l}\text { Fetal } \\
\text { urine }\end{array}$ & $\begin{array}{l}\text { Maternal } \\
\text { milk }\end{array}$ & $\begin{array}{l}\text { Maternal } \\
\mathrm{IgM} / \mathrm{IgG} \text { * }\end{array}$ & $\begin{array}{l}\text { Fetal NP } \\
\text { swab }\end{array}$ & $\begin{array}{l}\text { Fetal } \\
\text { urine }\end{array}$ & $\begin{array}{l}\text { Fetal } \\
\mathrm{IgM} / \mathrm{IgG} \text { * }\end{array}$ \\
\hline 2 & + & - & - & $\mathrm{N} / \mathrm{A}$ & N/A & $\mathrm{N} / \mathrm{A}$ & $\mathrm{N} / \mathrm{A}$ & N/A & $0 / 0$ & - & $\mathrm{N} / \mathrm{A}$ & $0 / 0$ \\
\hline 3 & + & - & - & - & - & - & - & - & $0 / 0$ & - & - & $0 / 0$ \\
\hline 4 & + & - & - & - & - & - & - & - & $0 / 0$ & - & - & $0 / 0$ \\
\hline 7 & + & - & - & - & - & - & - & - & $1.15 / 33.11$ & - & - & $0 / 46.17$ \\
\hline 8 & - & + & - & - & - & - & - & $\mathrm{N} / \mathrm{A}$ & $1.36 / 49.58$ & - & - & $0 / 52.52$ \\
\hline 9 & + & - & - & - & - & - & - & - & $0 / 0$ & - & - & $0 / 0$ \\
\hline 10 & - & - & - & - & - & - & - & - & $0 / 0$ & - & - & $0 / 0$ \\
\hline 11 & + & - & - & - & - & - & - & - & $0 / 0$ & - & - & $0 / 0$ \\
\hline
\end{tabular}

${ }^{*} \mathrm{IgM}$ and IgG results are expressed as arbitrary units per milliliter.

+, Positive reverse transcriptase PCR; -, negative reverse transcriptase PCR; N/A, not applicable because of unavailable samples; NP, nasopharyngeal.

encoding ubiquitin $\mathrm{C}$, to assess sample quality, whereas the negative probe was directed against bacterial gene DapB (catalog number 310043, EF191515, https://www.ncbi.nlm. nih.gov/nuccorelef191515, last accessed August 4, 2021) (Supplemental Figure S4). As a supplementary precaution, only diethylpyrocarbonate-treated water was used to avoid RNA degradation during the experiment.

\section{Human Primary Cytotrophoblast Isolation}

Placentas were collected from uncomplicated pregnancies at term to isolate and differentiate primary CTBs into STBs, following a previously validated protocol. ${ }^{23}$ Pieces of fresh placenta retrieved from uncomplicated pregnancy at term were digested with Dispase II and DNase I, grade II (Roche). The digested tissue was then sequentially filtered, and the cells were separated by density Percoll gradient centrifugation (GE Healthcare Bio-Sciences AB, Uppsala, Sweden). CTBs were cultured in Iscove's modified Dulbecco's medium (Gibco, Thermo Fisher Scientific) complemented with $50 \mu \mathrm{g} / \mathrm{mL}$ of gentamicin (Carl Roth $\mathrm{GmbH}$ \& Co, Karlsruhe, Germany) and 10\% of fetal bovine serum (Gibco, Thermo Fisher Scientific). Cultures were maintained up to 7 days in an atmosphere-controlled humidified incubator under $21 \% \mathrm{O}_{2}$ and $5 \% \mathrm{CO}_{2}$ at $37^{\circ} \mathrm{C}$.

\section{Exposure to SARS-CoV-2}

The SARS-Cov-2 strains were isolated from patient samples (clade 20E/EU1). At 24 or 96 hours after isolation, the cells were exposed to three concentrations of viral particles $\left(10^{9}\right.$, $10^{8}$, and $10^{7}$ copies $/ \mathrm{mL}$ ). Two hours after, the cells were washed three times with phosphate-buffered saline, and fresh medium was added. A negative control (uninfected cells) was included in each experiment, while Vero E6 cells (CRL-1586; ATCC, Manassas, VA) served as a positive control of the infection. Four days later, the supernatant was collected for rapid antigen assessment with CORIS COVID-19 Ag Respi-Strip (International Medical Products, Brussels, Belgium) and viral RNA detection by reverse

Table 5 Analysis of the 31 Placentas from COVID-19 Patients

\begin{tabular}{|c|c|}
\hline Variable & Value \\
\hline \multicolumn{2}{|l|}{ Macroscopy } \\
\hline \multicolumn{2}{|l|}{ Weight } \\
\hline Mean, $\mathrm{g}$ & $460.16(132.52)$ \\
\hline$<10$ th percentile, $\%$ & 21.43 \\
\hline \multicolumn{2}{|l|}{ Umbilical cord } \\
\hline Diameter, mm & $13.41(3.99)$ \\
\hline Velamentous insertion, $\%$ & 3.23 \\
\hline \multicolumn{2}{|l|}{ Observations, $\%$} \\
\hline Infarct & 19.35 \\
\hline Thrombohematoma & 16.13 \\
\hline Retroplacental hematoma & 9.68 \\
\hline \multicolumn{2}{|l|}{ Microscopy, \% } \\
\hline \multicolumn{2}{|l|}{ Maternal vascular malperfusion } \\
\hline Distal villous hypoplasia & 16.13 \\
\hline Decidual arteriopathy & 3.23 \\
\hline Villous hypermaturity & 6.45 \\
\hline Nuclear clusters & 35.48 \\
\hline Fibrin deposits & 38.71 \\
\hline Chronic histiocytic intervillositis & 9.68 \\
\hline \multicolumn{2}{|l|}{ Chorioamnionitis } \\
\hline Focal & 16.13 \\
\hline Diffuse & 6.45 \\
\hline With fetal response & 3.23 \\
\hline Choriangiomatosis & 16.13 \\
\hline Parabasal calcifications & 35.48 \\
\hline \multicolumn{2}{|l|}{ SARS-CoV-2 detection, $\%$} \\
\hline Reverse transcriptase PCR & 16.13 \\
\hline Immunohistochemistry & 3.23 \\
\hline In situ hybridization & 3.23 \\
\hline
\end{tabular}

Data are presented as means (SD), unless otherwise indicated. 
A

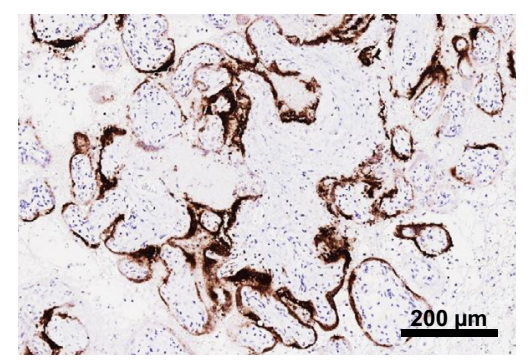

B

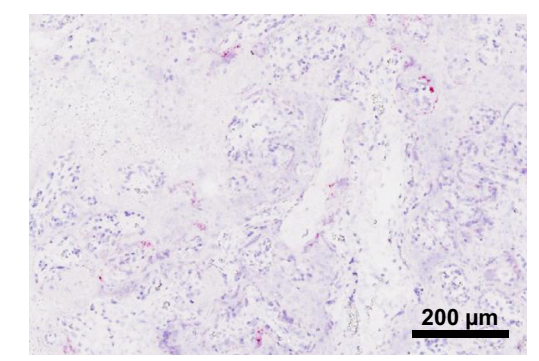

C

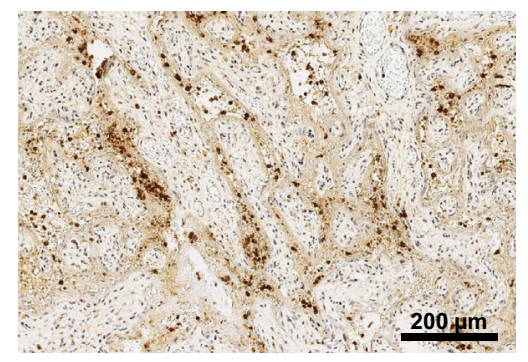

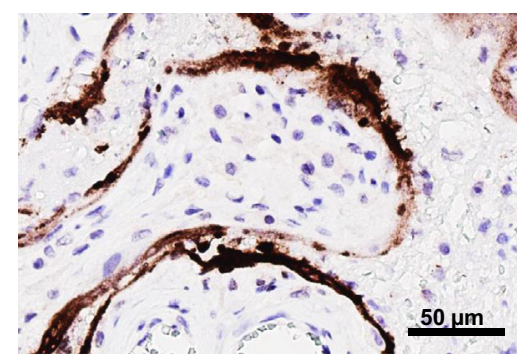
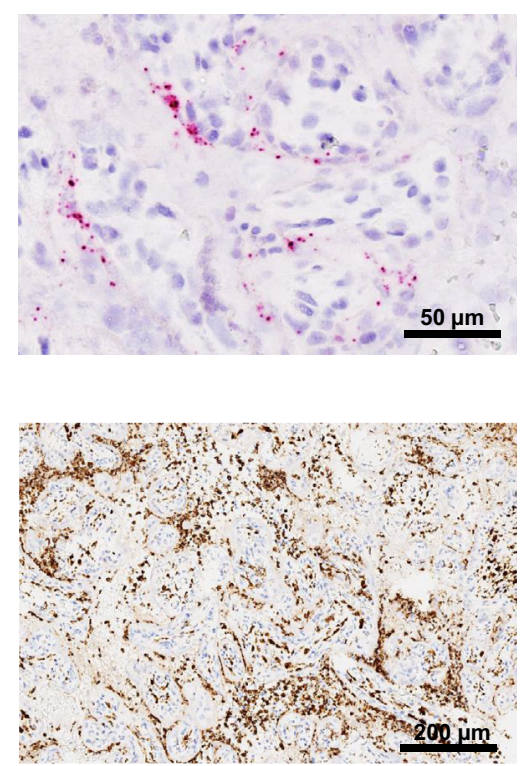

Figure 1 SARS-CoV-2 can infect preterm placenta and induce diffuse subacute intervillitis. A: The SARSCoV-2 nucleocapsid was visualized in the syncytium by immunostaining (brown), at low (left panel) and high (right panel) magnification factor. B: Immunostaining was confirmed by in situ hybridization (red dots), at low (left panel) and high (right panel) magnification factor. C: Confirmation of chronic histiocytic intervillositis by immunostaining (brown) of CD3, a marker of T lymphocytes (left panel), and CD68, a marker of macrophages (right panel). Images are representative of the whole tissue section. Scale bars: $200 \mu \mathrm{m}$ (A and B, left panels, and C, left and right panels); $50 \mu \mathrm{m}$ (A and $\mathbf{B}$, right panels). transcriptase PCR. The cells were also fixed with methanol to detect the viral nucleocapsid by immunofluorescence.

\section{TMPRSS2 Overexpression}

Thirty-six hours after isolation (day 2), primary CTBs were transfected with a vector expressing the human isoform 1 of TMPRSS2 by using the Lipofectamine 3000 Transfection Reagent (Invitrogen, Thermo Fisher Scientific). DNA $(1 \mu \mathrm{g})$ was used in a 12-well format, according to manufacturer's protocol. The plasmid was a gift from Roger Reeves (plasmid number 53887; Addgene, Watertown, MA). ${ }^{24}$

\section{Relative Gene Expression}

Total RNA was extracted from cells using PureLink RNA Mini Kit (Invitrogen, Thermo Fisher Scientific), followed by reverse transcription using qScript cDNA SuperMix (Quanta Biosciences, Gaithersburg, MA). Quantitative realtime PCR was performed with $5 \mathrm{ng}$ of cDNA and $0.2 \mu \mathrm{mol} /$ L of specific primers (Table 2) in Takyon ROX SYBR $1 \times$ MasterMix dTTP blue (Eurogentec) on a StepOne RealTime PCR System (Applied Biosystems, Thermo Fisher
Scientific). The relative expression ratio of a target gene was calculated following the Pfaffl method, using succinate dehydrogenase A (SDHA) and TATA-box binding protein $(T B P)$ as reference genes. ${ }^{25}$

\section{Protein Analysis}

Whole-cell lysates were prepared using radioimmunoprecipitation assay buffer (Merck, Burlington, MA) supplemented with Halt Protease Inhibitor Cocktail $1 \times$ (Thermo Scientific, Thermo Fisher Scientific). For Western blot analysis, $20 \mu \mathrm{g}$ of proteins was reduced and proceeded according to a previously published protocol. ${ }^{26}$ Proteins were loaded onto a $10 \%$ Acrylamide/Bisacrylamide Bolt Bis-Tris mini gel (Invitrogen, Thermo Fisher Scientific) and transferred onto an Invitrolon polyvinylidene difluoride membrane (Invitrogen, Thermo Fisher Scientific). Then, the membrane was blocked before being incubated overnight at $4^{\circ} \mathrm{C}$ with the primary antibodies (Table 1 ). The day after, the membrane was washed and incubated for 1 hour with horseradish peroxidase-conjugated secondary antibodies at room temperature (Table 1). Bound antibodies were detected using the SuperSignal West Pico PLUS 
A

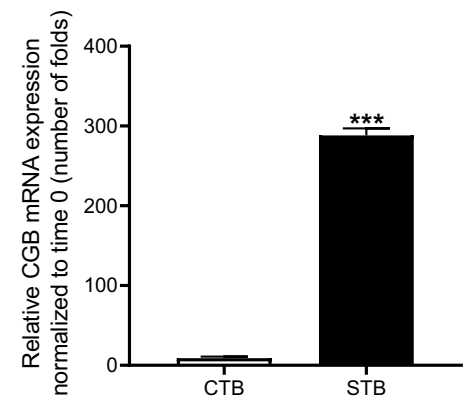

D

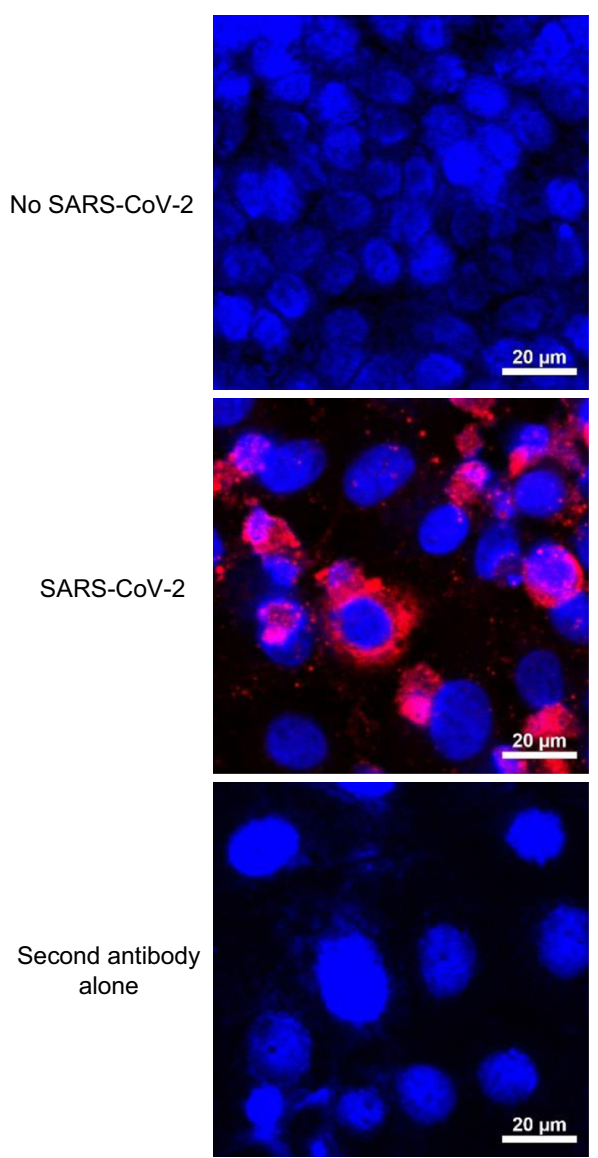

B

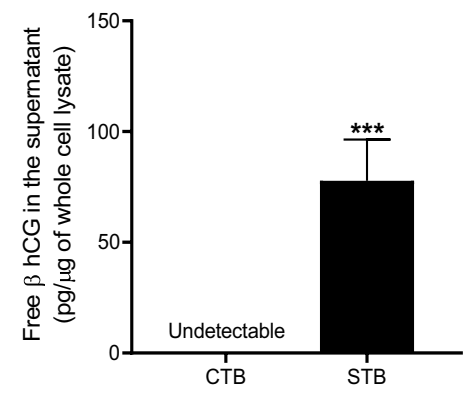

C

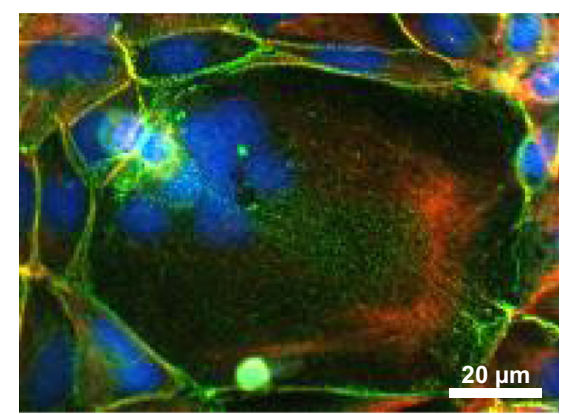

CTB
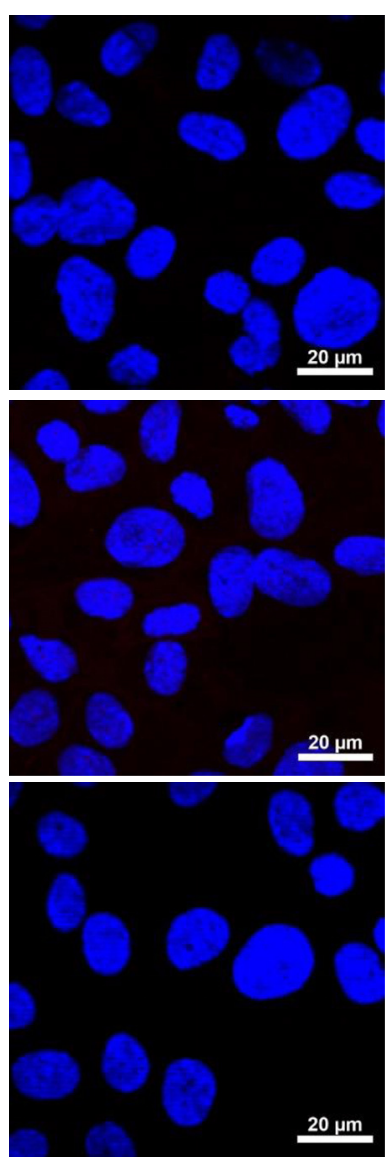

STB
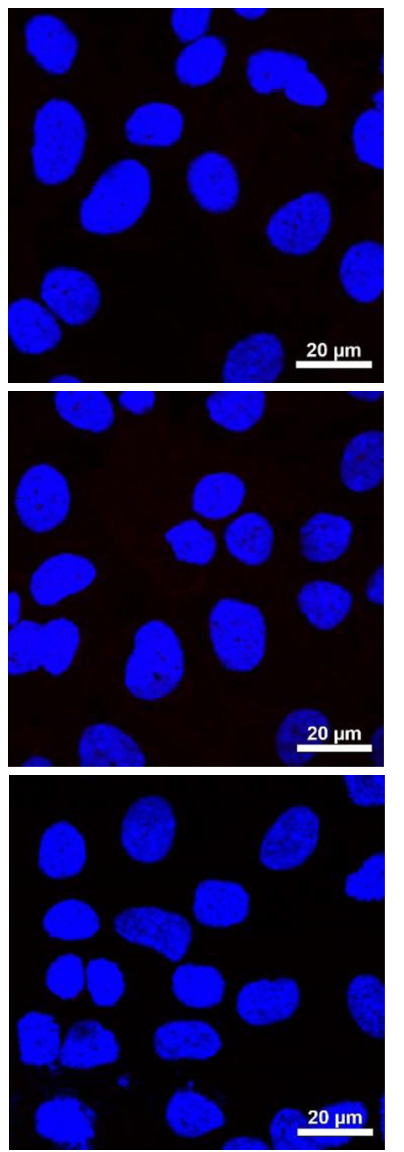

Figure 2 Primary human trophoblasts at term are resistant to SARS-CoV-2 infection. A: Primary human cytotrophoblasts (CTBs) were fully differentiated into syncytiotrophoblasts (STBs) after 4 days of culture, as illustrated by an exponential increase in human chorionic gonadotrophin expression $(C G B)$. B: This was confirmed by measuring free $\beta$ human chorionic gonadotropin (hCG) in the supernatant by enzyme-linked immunosorbent assay. C: Multinucleated syncytiotrophoblasts expressing cytokeratin 7 were visualized after 4 days in culture (nuclei in blue, cell membranes in green, and cytokeratin 7 in red). D: Primary CTBs and STBs were exposed to SARS-CoV-2 and fixed with methanol 4 days later. Top panels: Vero E6 cells were used as positive control, whereas negative control consisted of unexposed cells. The viral nucleocapsid was observed only in Vero E6 cells (nuclei in blue and viral nucleocapsid in red; middle left panel), whereas the secondary antibody alone was specific (bottom panels). The experiments were repeated three times in duplicates. Images are representative of each condition, and acquisition parameters/histograms are similar between images. All data are shown as means \pm SEM (A and $\mathbf{B})$. $n=3$ human placentas (A-D); $n=6$ for data in duplicates (A and $\mathbf{B})$. ${ }^{* * *} P<0.001$ versus first column (by $t$-test). Scale bar $=20 \mu \mathrm{m}(\mathbf{C}$ and $\mathbf{D})$. 
chemiluminescent substrate (Thermo Fisher Scientific) and Amersham Hyperfilm ECL films (GE Healthcare Limited, Chicago, IL).

The supernatant of the last 24 hours was conserved to assess biochemical differentiation of the trophoblasts. Total secreted free $\beta$-subunit human chorionic gonadotrophin was quantified with a B.R.A.H.M.S. Kryptor Compact Plus immune analyzer (Thermo Fisher Scientific) and normalized to whole-cell lysates extracted from the same well.

\section{Immunofluorescence}

Cells were cultured in CELLview (Greiner Bio-One International $\mathrm{GmbH}$, Kremsmünster, Austria). They were fixed with methanol for the detection of intracellular proteins or Image-iT Fixative Solution (methanol-free 4\% formaldehyde; Invitrogen, Thermo Fisher Scientific) for the detection of membrane proteins. Specific primary antibodies were added to the wells and incubated overnight at $4^{\circ} \mathrm{C}$ (Table 1 ). The day after, the wells were washed and incubated with the appropriate secondary antibodies. Nuclei were counterstained with NucBlue when mounting slides with ProLong Glass Antifade Mountant (Invitrogen, Thermo Fisher Scientific). Fluorescence was examined on an AxioImager microscope combined with ApoTome (Zeiss, Oberkochen, Germany) or on an LSM 800 confocal microscope (Zeiss). Acquisition parameters and color histograms were kept similar between conditions.

\section{Tissue Staining Quantification}

Expression of ACE2 and TMPRSS2 during pregnancy was quantified by IHC in retrospectively collected formalinfixed, paraffin-embedded placentas from 2017. This study was approved by the Ethical Committee of the Catholic University of Louvain (approval number 2018/23OCT/397) and with the consent of the patients. Samples were retrieved from spontaneous abortion (before 22 weeks), uncomplicated preterm pregnancies (before 37 weeks of gestation), and term pregnancies (between 37 and 41 weeks of gestation). According to the institutional procedure, all of the collected cases were analyzed by a pathologist and diagnosed as nonpathologic. Histologic slides from recruited placentas were incubated with primary antibodies overnight at $4^{\circ} \mathrm{C}$ (Table 1). Immunohistochemical reactions were visualized with the EnVision+ System (Dako, Agilent Technologies, Santa Clara, CA), which is a horseradish peroxidase-labeled polymer conjugated with secondary antibodies. Sites of binding were revealed by treatment with diaminobenzidine (Dako, Agilent Technologies). Kidney (ACE2-positive) ${ }^{27}$ or prostate adenocarcinoma (TMPRSS2positive $)^{28}$ tissue sections were used as positive controls, whereas negative controls consisted of slides incubated with secondary antibodies alone. Stained slides were digitalized using an SCN400 slide scanner (Leica Biosystems, Wetzlar, Germany) at $\times 20$ magnification. Scanned slides were analyzed by the image analysis tool author version 2017.2 (Visiopharm, Hoersholm, Denmark), following the workflow described in Supplemental Figure S5.

\section{Statistical Analysis}

All graphs show means \pm SEMs, and the tables show means \pm SDs. Statistical analyses were performed on GraphPad Prism 8 (GraphPad Software, La Jolla, CA), using $t$-test or one-way analysis of variance, followed by the Dunnett post-hoc test. $P<0.05$ was considered to be statistically significant. Each in vitro experiment was repeated three times ( $N=3$ human placentas) in technical duplicates $(n=6)$. Quantification of ACE2 and TMPRSS2 by IHC was performed on three random fields from 35 placentas $(N=35$ placentas $)$ with technical triplicates $(n=105)$.

\section{Results}

Reassuring Maternal and Neonatal Outcomes in COVID19 Pregnancies at Term

Thirty-one pregnant women who delivered after 22 weeks and who were tested positive for SARS-CoV-2 during their pregnancy were included in the study. Maternal and fetal characteristics are described in Table 3. Gestational age was estimated from the first day of the last menstrual period and confirmed by first-trimester ultrasound examination. Twentyseven patients tested positive during their third trimester, mainly the week before childbirth. Of these patients, 18 were asymptomatic, five had mild symptoms (fatigue, anosmia, or ageusia), and four had moderate symptoms, including fever and dyspnea. In most cases, the pregnancy ended without complications, and the mothers gave birth to healthy neonates. Four patients tested positive before 30 weeks of gestation. The first one had fever associated to dyspnea. She was diagnosed at 26 weeks 3 days of gestation and gave birth prematurely by cesarean section because of severe preeclampsia. The baby was growth-restricted and tested positive for SARS-CoV-2 by reverse transcriptase PCR, but 7 days after birth. ${ }^{29}$ The second patient was tested at 28 weeks 6 days of gestation. She was hospitalized in the intensive care unit for 14 days for severe respiratory distress, but was able to give birth at term without complications. The third patient tested positive at 23 weeks 3 days of gestation because of dyspnea. She delivered a viable polymalformed newborn (esophageal atresia, anal imperforation, Fallot tetralogy, and multicystic kidney) at 33 weeks 1 day. The CHARGE syndrome (coloboma, heart defects, choanal atresia, retardation of growth and/or development, genitourinary malformation, and ear abnormalities and/or deafness) was excluded by genomic analysis, but the malformations remained compatible with a VACTERL association (vertebral defects, anal atresia, cardiac defects, tracheo-esophageal fistula, renal anomalies, and limb abnormalities). The last patient was 
A

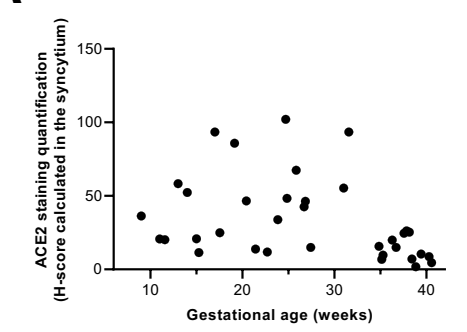

C

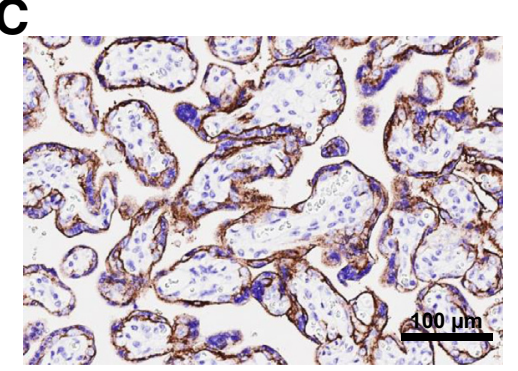

E

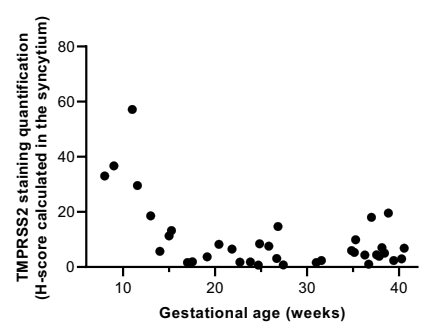

G

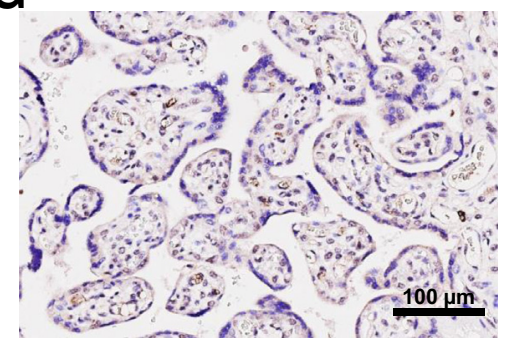

B

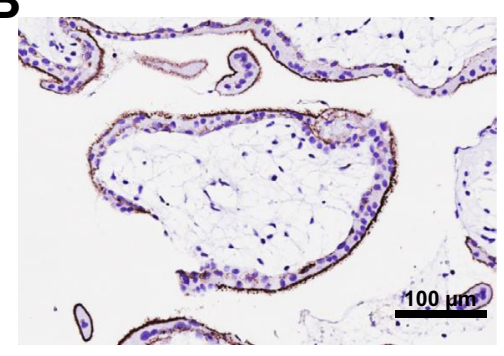

D

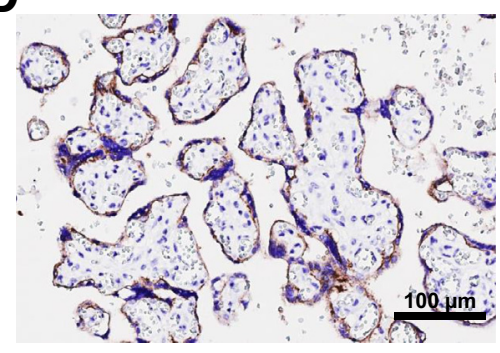

$F$

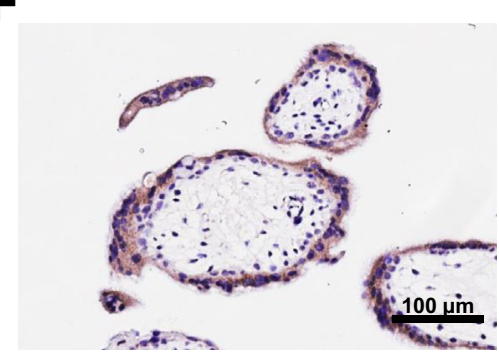

H

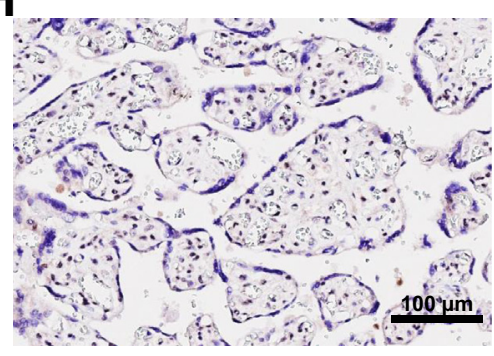

Figure 3 The co-expression of SARS-CoV-2 host membrane receptors angiotensin-converting enzyme 2 (ACE2) and transmembrane protease serine 2 (TMPRSS2) is low after 30 weeks of gestation. A: Expression of ACE2 at different gestational ages is quantified with computer assistance. The histologic score (H-score) demonstrates that ACE2 expression is particularly high before 30 weeks of gestation, even if a certain degree of interindividual variability is observed. B: Representative images of ACE2 staining. First-trimester placenta from spontaneous abortion. C: Second-trimester placenta from uncomplicated preterm delivery. D: Placentas at term from uncomplicated pregnancy. E: Same as A, but for TMPRSS2. The general Hscore is lower than for ACE2 and drastically decreases after 15 weeks of gestation. F: Representative images of TMPRSS2 staining. First-trimester placenta from spontaneous abortion. G: Second-trimester placenta from uncomplicated preterm delivery. H: Placenta at term from uncomplicated pregnancy. Images are representative of the whole tissue section. Computer-assisted quantification was performed on three random fields from 35 placentas in triplicates. $n=35$ placentas (A and $\mathbf{E}$ ); $n=105$ for data in triplicates (A and E). Scale bar $=100 \mu \mathrm{m}$ (B-D and $\mathbf{F}-\mathbf{H})$. referred to obstetrical emergency at 25 weeks 2 days for a fever peak at $39^{\circ} \mathrm{C}$, decreased fetal movements, and ultrasonographic signs of fetal distress. A diagnosis of intrauterine fetal demise was made on admission. A positive nasopharyngeal swab of the mother confirmed the medical history, which was compatible with a COVID-19 infection contracted a few days ago.

\section{Maternal SARS-CoV-2 IgG Antibodies Are Transferred to the Fetus}

Additional samples were available for the first 12 patients in our cohort (Table 4). The virus was detected only in the maternal plasma of the intensive care unit patient during her hospitalization. All patients gave birth to healthy babies at term, and none of the babies tested positive for SARS-CoV-2 by reverse transcriptase PCR on a nasopharyngeal swab performed just after delivery. Several mothers in our cohort had SARS-CoV-2 IgM and/or IgG, but their newborns only had IgG, suggesting passive antibody transfer across the placenta.

\section{Analysis of the Placentas Retrieved from SARS-CoV-2 Patients}

A studied piece of placenta and the amniotic membrane from all patients were available for the detection of SARS-CoV-2 by reverse transcriptase PCR (Table 5). The placenta from the intrauterine death was highly positive $\left(\mathrm{C}_{\mathrm{T}}\right.$, around 15$)$, whereas three placentas were at the limit of detection $\left(\mathrm{C}_{\mathrm{T}}\right.$, around 40$)$. Localization of the virus was further confirmed by IHC and ISH. The nucleocapsid (Figure 1A) and the viral RNA (Figure 1B) were detected only in the syncytium of the demised fetus. 
Although analysis of the 31 placentas did not reveal any specific histologic pattern, six cases showed different signs of maternal vascular malperfusion, as per the Amsterdam consensus. ${ }^{30}$ Besides, chronic histiocytic intervillositis was diagnosed in three placentas, including the SARS-CoV$2-$ positive placenta, in which the presence of lymphocytes and macrophages in the intervillous space was confirmed by CD3 and CD68 immunostaining, respectively (Figure 1C). Focal or diffuse chorioamnionitis was observed in eight placentas. However, the medical significance of these diagnostics is uncertain as they were not clearly associated with maternal symptoms or neonatal infection.

Regarding the intrauterine demise case, autopsy did not reveal any sign of systemic infection as the histology of the organs was normal. However, a diagnosis of pneumonia could not be excluded because of the presence of polynuclear neutrophils in the alveoli. No SARS-CoV-2 nucleocapsid and RNA were detected by IHC and ISH in lung, kidney, heart, intestinal tract, thyroid, spleen, liver, pancreas, testes, cerebellum, or eye tissues (Supplemental Figure S6).

\section{Trophoblasts Are Not Susceptible to Infection by SARS- CoV-2}

As placenta at term constitutes a natural barrier against the maternal pathogens, our hypothesis was that the trophoblasts were not susceptible to SARS-CoV-2 infection, regardless of their state of differentiation. To test this hypothesis, we first isolated mononuclear CTBs from human placentas at term and differentiated them in vitro. Forty-eight hours after isolation, the cells started expressing chorionic gonadotrophin chain $\beta$ (CGB) mRNA (Figure 2A) and secreting a high amount of free $\beta$ human chorionic gonadotropin in the supernatant (Figure 2B). In addition, plurinuclear cells expressing cytokeratin 7 were visualized, suggesting an adequate differentiation of the cells (Figure 2C). ${ }^{31}$

To assess their vulnerability to SARS-CoV-2 infection, undifferentiated (CTB, 48 hours after isolation) and differentiated (STB, 96 hours after isolation) trophoblasts were exposed to increasing amounts of SARS-CoV-2 virions in the medium. Four days after, viral antigens or RNA was not detected in the culture media. On the other hand Vero E6 cells, known to be vulnerable to SARS-CoV-2, ${ }^{32}$ were infected and released a high number of viruses in the supernatant. This finding was further confirmed by the presence of the nucleocapsid of the virus in the cytoplasm of Vero E6, but not in primary trophoblasts by immunofluorescence (Figure 2D). As expected, the cytopathic effects were obvious in the infected Vero E6, whereas there was no difference between the infected trophoblast cultures and controls (Supplemental Figure S7).

\section{Trophoblasts Poorly Co-Express ACE2 and TMPRSS2 at Term}

As mentioned, combined ACE2 and TMPRSS2 expression at the cell surface could be considered as a biological indicator of susceptibility to SARS-CoV-2 infection. Compared with lung and kidney tissues, the placenta at term expressed ACE2 moderately (Supplemental Figure S8A) but not TMPRSS2 (Supplemental Figure S8B). Computer-assisted quantification demonstrated that ACE2 expression in placentas from different gestational ages decreased from the second trimester to term (Figure 3, A-D), whereas TMPRSS2 expression almost disappeared after 15 weeks of gestation (Figure 3, E-H). High-magnification analysis of the placentas at term showed that ACE2 was expressed at the apical and the basolateral poles of STBs (Figure 4A), whereas TMPRSS2 was only expressed by CTBs (Figure 4B). This finding was further confirmed by quantitative real-time PCR and Western blot analysis in our primary cell cultures: CTBs expressed TMPRSS2, whereas the STBs highly expressed ACE2 (Figure 4, C and D).

\section{Induction of TMPRSS2 Expression by} Syncytiotrophoblasts Is Not Sufficient to Allow SARSCoV-2 Entry and Replication

Given expressional observations, we envisioned that the syncytium at term was protected from SARS-CoV-2 infection because of the absence of TMPRSS2 at its surface. To confirm this hypothesis, differentiated STBs were transfected with an expression vector of TMPRSS2 48 hours before exposure to SARS-CoV-2 virions. TMPRSS2 expression was verified by quantitative real-time PCR (Figure 5A) and Western blot analysis (Figure 5B), whereas its localization was specified by immunofluorescence (Figure 5C) before adding viral particles to the culture medium. Surprisingly, SARS-CoV-2 could not be detected in the supernatant by reverse transcriptase PCR nor in the cells by immunofluorescence (Figure 5D), suggesting that transient expression of TMPRSS2 is not sufficient to allow the entry of the virus or its replication in differentiated trophoblasts.

\section{Discussion}

Data from the present study confirmed that the vertical transmission of SARS-CoV-2 is a rare event, and does not usually occur around the term of a pregnancy. Analysis of the clinical samples showed that maternal infection does not easily spread to the fetus, but the consequences can be dramatic. Isolated cases of vertical transmission are regularly published, but their validity must be taken with caution because a pertinent diagnostic classification is rarely used. ${ }^{33}$ Indeed, most of the reported neonatal infections are only diagnosed by reverse transcriptase PCR on a nasopharyngeal swab without evidence of viral RNA in the fetal blood or in the amniotic fluid. Besides, the occurrence of intrauterine transplacental transmission should be based on the 
A

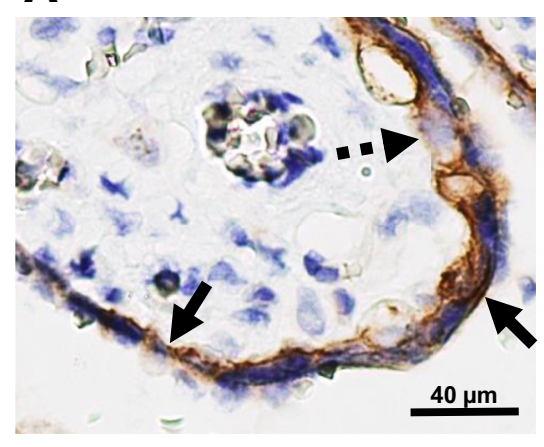

B

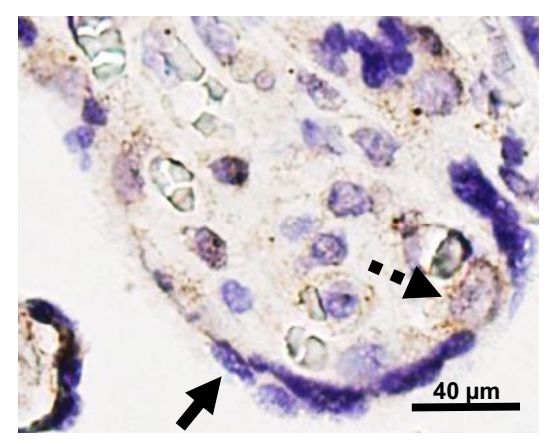

Figure 4 The syncytium at term highly expresses angiotensin-converting enzyme 2 (ACE2) but not transmembrane protease serine 2 (TMPRSS2). A: Immunostaining of ACE2 visualized in the villi at term at high magnification. The staining is mainly localized in the multinucleated syncytiotrophoblasts (STBs), both at the apical and the basolateral poles (full arrows), whereas the mononucleated cytotrophoblasts (CTBS) are negative (discontinuous arrow). B: Immunostaining of TMPRSS2 visualized in the villi at term at high magnification. STBs are negative (full arrow), whereas CTBs are weakly positive (discontinuous arrow). C: Expression of ACE2 is determined in CTBs and STBs by quantitative realtime PCR and Western blot analysis. As observed by immunohistochemistry, CTBs poorly express ACE2, whereas STBs are highly positive. D: Same as B, but for TMPRSS2. Unlike ACE2, TMPRSS2 was moderately expressed by CTBs but not by STBs. Experiments were repeated three times in duplicates. Images are representative of the whole tissue section. All data are shown as means \pm SEM (C and D). $n=3$ human placentas (C and $\mathbf{D}$ ); $n=6$ for data in duplicates (C and $\mathbf{D}) .{ }^{*} P<0.05$, ${ }^{* *} P<0.01$ versus first column (by $t$-test). Scale bar $=40 \mu \mathrm{m}(\mathbf{A}$ and $\mathbf{B})$. Original magnification, $\times 400$ (A). GAPDH, glyceraldehyde-3-phosphate dehydrogenase.

identification of SARS-CoV-2 in chorionic villi. ${ }^{34}$ Given that, what is the appropriate method of detection?

On the one hand, several studies report the detection of SARS-CoV-2 in the placenta by reverse transcriptase PCR on RNA extracted from the whole tissue, or from a swab realized on the chorionic plate. This technique is nonspecific, as the sample can be contaminated by maternal cells and/or vaginal secretions in case of vaginal delivery. ${ }^{35}$ In the current cohort, three cases were weakly positive without confirmation by other methods. On the other hand, although proving the presence of viral proteins in the placenta by IHC would have been a practical technique, most anti-SARSCoV-2 antibodies developed for immunostaining lack specificity in practice. ${ }^{36}$ For instance, the anti-spike antibodies had to be excluded of the study as they showed specificity problems (Supplemental Figures S1 and S2). Yet, the anti-nucleocapsid antibody showed a higher specificity (Supplemental Figure S3). It is therefore difficult to trust findings based on one antibody alone. In this context, ISH appears to be the solution, but its implementation is limited because it requires specific expertise, a substantial budget, and good-quality samples. Finally, a few studies localized viral particles in the syncytium by electron microscopy. ${ }^{37,38}$ Although interesting, these observations have been controversial because of the difficulty in distinguishing viral particles from cellular components. ${ }^{39,40}$ Like immunostaining, electron microscopy should be used in combination with other methods, including the histologic diagnosis. Isolated cases of positive placentas identified by IHC and/or ISH have been reported. ${ }^{13,41}$ All of the infected placentas were characterized by the prominent positivity of STBs for SARS-CoV-2, an unusual chronic histiocytic intervillositis, and syncytial necrosis. ${ }^{42}$ Conversely, the uninfected placentas showed significant variability in the spectrum of pathology findings, in spite of the maternal vascular malperfusion features being preferentially associated with adverse outcomes. $^{43}$

As observed in our cohort, direct interactions between SARS-CoV-2 and STBs are possible in vivo. For this reason, undifferentiated and differentiated trophoblasts were directly exposed to different concentrations of SARS-CoV-2 virions. These concentrations were much higher than observed in the blood of the hospitalized patient $\left(<10^{5}\right.$ copies $/ \mathrm{mL}$ ). This set of data is unprecedented, as primary cells isolated from human placentas at term were cultured with real viral particles for the first time. Only one publication has shown that SARS-CoV-2 pseudovirus can eventually enter CTBs, but neither the localization nor the replication of the virus has been studied. ${ }^{44}$ By contrast, the current experiments clearly demonstrated that term trophoblasts, irrespective of their state of differentiation, are resistant to SARS-CoV-2 infection.

The resistance is speculated to be conferred by the low co-expression of ACE2 and TMPRSS2 by STBs. ${ }^{45}$ In this study, the findings from single-cell RNA-sequencing data were confirmed, and the expression of ACE2 and TMPRSS2 in the syncytial area was reliably quantified over the weeks of gestation..$^{20,46}$ In addition to low 
A

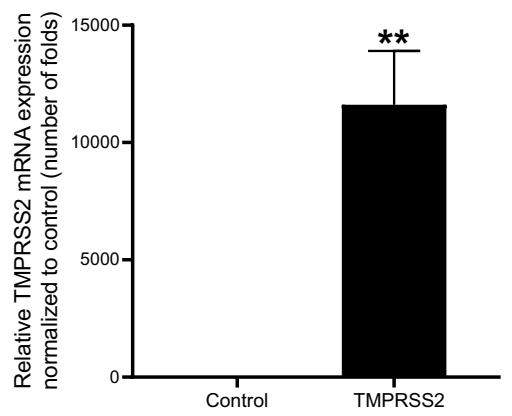

D

No SARS-CoV-2

SARS-CoV-2

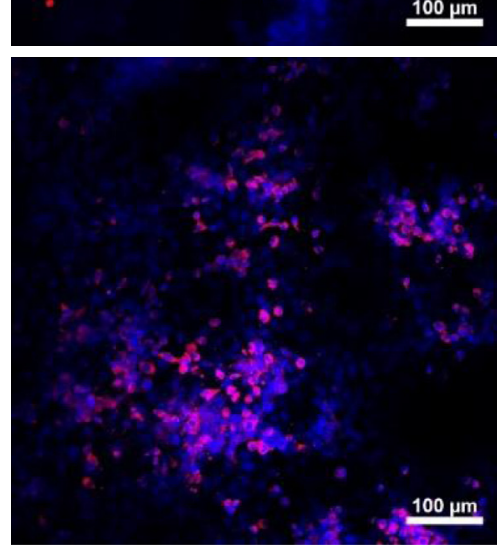

Vero E6
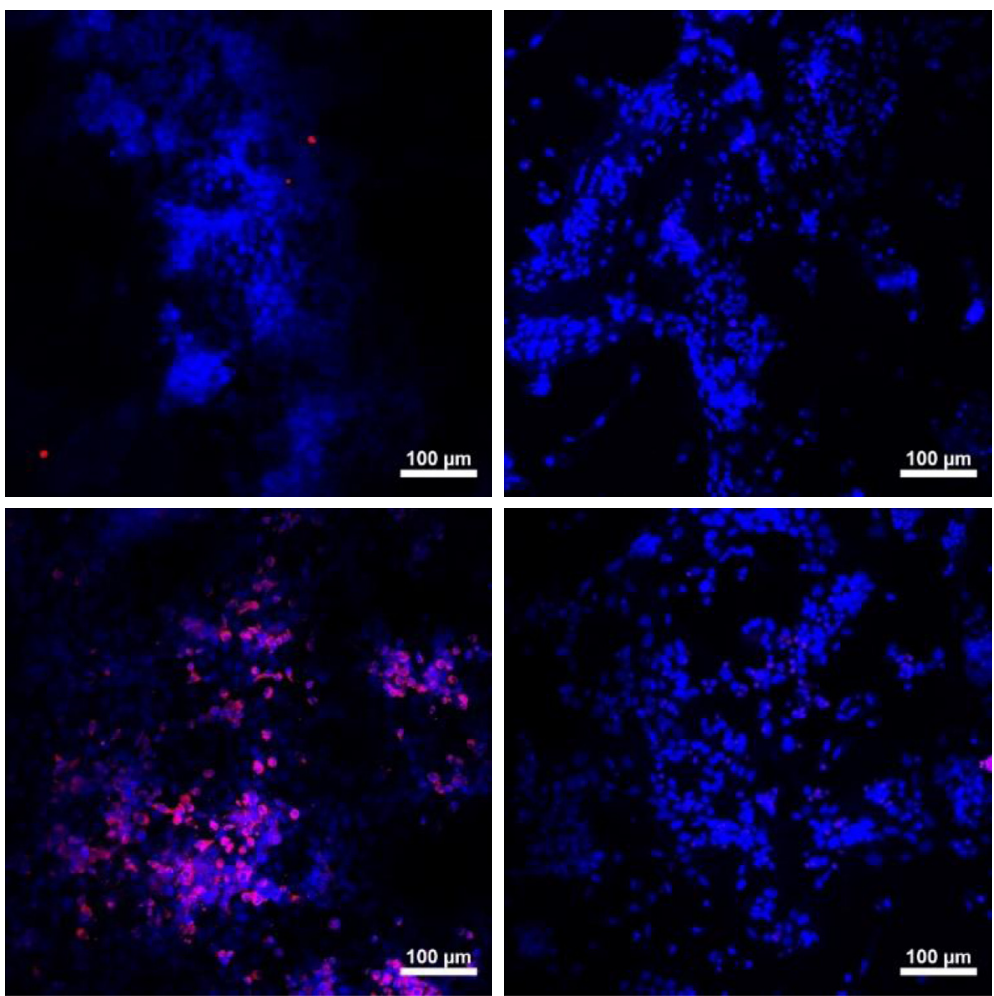

C

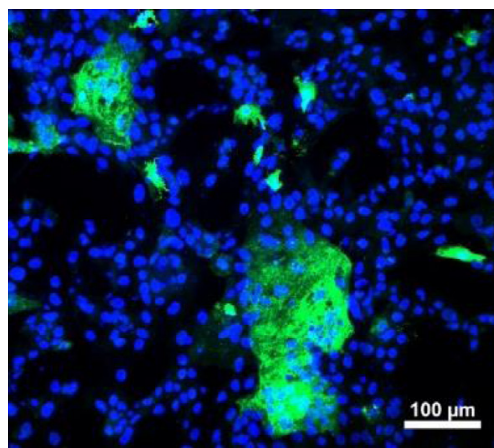

STB + TMPRSS2
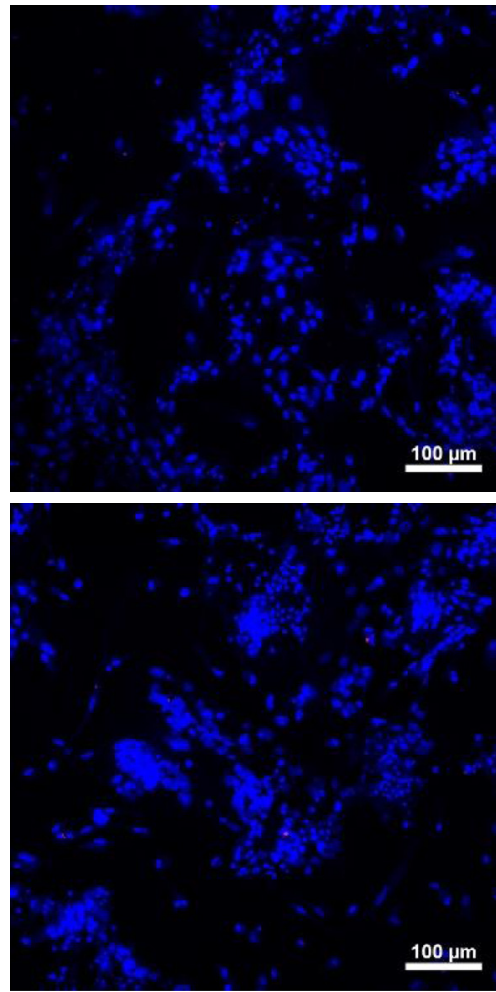

Figure 5 The transient expression of transmembrane protease serine 2 (TMPRSS2) in the syncytiotrophoblasts (STBs) is not sufficient to allow SARS-CoV-2 entry and replication. A: Primary human cytotrophoblasts were transfected 48 hours after differentiation with an empty vector (control) or a vector expressing TMPRSS2. A and B: Before exposure to SARS-CoV-2, expression of TMPRSS2 was assessed by quantitative real-time PCR (A) and Western blot analysis (B). C: Localization of the protein is shown by immunofluorescence (nuclei in blue and TMPRSS2 in green). D: Control STBs and pTMPRSS2-transfected STBs were exposed to SARS-CoV-2 and fixed with methanol 4 days later. Top panels: Vero E6 cells were used as positive control, whereas negative control consisted of unexposed cells. Bottom left panel: The viral nucleocapsid was observed only in Vero E6 cells (nuclei in blue and viral nucleocapsid in red). The experiments were repeated three times in duplicates. Images are representative of each condition, and acquisition parameters/color histograms were kept similar. All data are shown as means \pm SEM $(\mathbf{A}) . n=3$ human placentas $(\mathbf{A}-\mathbf{D}) ; n=6$ for data in duplicates $(\mathbf{A}) .{ }^{*} p<0.01$ versus first column (by $t$-test). Scale bar $=100$ $\mu \mathrm{m}$ (C and D). GAPDH, glyceraldehyde-3-phosphate dehydrogenase.

TMPRSS2 expression by the syncytium, a polarized pattern of ACE2 with the highest expression on the stromal side of the STBs has been suggested. ${ }^{47}$ However, in the current study, the immunostaining was both localized on the basolateral and the apical sides of the syncytium. Additionally, immunostaining of ACE2 and TMPRSS2 did not appear stronger than in the infected placenta of similar gestational age (Supplemental Figure S9).
To assess the essential role of TMPRSS2 for viral entry, its transient expression was induced in fully differentiated trophoblasts, which were exposed to SARS-CoV-2. Surprisingly, expressing the isoform 1 of TMPRSS2 was not sufficient to lead to the infection of the cells. Even if the expression is confirmed by different techniques, it is difficult to prove that the produced protein is fully functional and localizes at the membrane. For instance, alternative 
splicing could explain the inability of the expressed TMPRSS2 to prime the spike protein. Interestingly, TMPRSS2 transcription is under androgen regulation, and androgen receptor inhibitors were found to be protective against SARS-CoV-2 infection. ${ }^{48,49}$ As progesterone has anti-androgenic effects, the high production of progesterone by the syncytium could also explain the natural protection of the placenta against the virus. ${ }^{50}$

It is important to acknowledge that the role of TMPRSS2 has been highlighted by knockdown or overexpression techniques in already infectable cells, including enterocytes or Vero E6 cells. ${ }^{51,52}$ Besides, recent studies indicate the existence of other proteases and host factors required to permit SARS-CoV-2 entry. ${ }^{53-55}$ Therefore, it is important to admit that the entry processes by which SARS-CoV-2 infects human cells are far more complex than initially hypothesized, and do not depend only on the co-expression of ACE2 and TMPRSS2. Lastly, even if vertical transmission does occur, described immunomodulatory mechanisms used by the placenta may mitigate the transmission of the virus to the fetus. ${ }^{56,57}$

The current study combined clinical and in vitro evidence about placental infection by SARS-CoV-2. To the best of our knowledge, it is the first reported case of intrauterine fetal death associated with maternal COVID-19 positivity and documented infection of the placenta. A robust model of trophoblast isolation and differentiation method demonstrated that a low co-expression of ACE2 and TMPRSS2 at the surface of the syncytium alone is not sufficient to explain the resistance of the placenta against SARS-CoV2 at term. To conclude, this work emphasizes the need for further explorations of the vertical transmission of SARS$\mathrm{CoV}-2$ during pregnancy and the systematic screening for the virus in case of neonatal infection.

\section{Acknowledgments}

We thank the physicians (Pierre Bernard, Mina MhallemGziri, Patricia Steenhaut, Julie Van Der Monde, Auriane Van Grambezen, Jean-Marc Biard, Guillaume De Galan, and Emmanuelle Renkin), the residents in obstetrics/gynecology, and the midwives of the Saint-Luc University Hospital for the recruitment of patients; the biobank of Saint-Luc University Hospital for providing access to formalin-fixed, paraffin-embedded placenta collection; Charles Pilette and Johann Morelle for providing access to lung and kidney biopsies; Damien Gruson for human chorionic gonadotropin measurements; and Caroline Bouzin and Michèle De Beukelaer (2IP imaging platform) for technical support regarding tissue staining.

\section{Author Contributions}

A.C., C.H., and F.D. designed the clinical study. A.C., C.L.D., and G.D. designed and performed in vitro experiments. A.C. and P.B. did histological analysis of formalin-fixed, paraffin-embedded samples. P.S. and F.D. supervised the work and provided funding. All authors were involved in writing the article and had final approval of the submitted and published versions. A.C. is the guarantor of this work and, as such, had full access to all of the data in the study and takes responsibility for the integrity of the data and the accuracy of the data analysis.

\section{Supplemental Data}

Supplemental material for this article can be found at http://doi.org/10.1016/j.ajpath.2021.05.009.

\section{References}

1. Qiao J: What are the risks of COVID-19 infection in pregnant women? Lancet 2020, 395:760-762

2. Di Mascio D, Khalil A, Saccone G, Rizzo G, Buca D, Liberati M, Vecchiet J, Nappi L, Scambia G, Berghella V, D'Antonio F: Outcome of coronavirus spectrum infections (SARS, MERS, COVID-19) during pregnancy: a systematic review and meta-analysis. Am J Obstet Gynecol MFM 2020, 2:100107

3. Karimi L, Makvandi S, Vahedian-Azimi A, Sathyapalan T, Sahebkar A: Effect of COVID-19 on mortality of pregnant and postpartum women: a systematic review and meta-analysis. J Pregnancy 2021, 2021:8870129

4. Allotey J, Stallings E, Bonet M, Yap M, Chatterjee S, Kew T, Debenham L, Llavall AC, Dixit A, Zhou D, Balaji R, Lee SI, Qiu X, Yuan M, Coomar D, van Wely M, van Leeuwen E, Kostova E, Kunst H, Khalil A, Tiberi S, Brizuela V, Broutet N, Kara E, Kim CR, Thorson A, Oladapo OT, Mofenson L, Zamora J, Thangaratinam S; on behalf of the PregCOV-19 Living Systematic Review Consortium: Clinical manifestations, risk factors, and maternal and perinatal outcomes of coronavirus disease 2019 in pregnancy: living systematic review and meta-analysis. BMJ 2020, 370:m3320

5. Huntley BJF, Mulder IA, Di Mascio D, Vintzileos WS Vintzileos AM, Berghella V, Chauhan SP: Adverse pregnancy outcomes among individuals with and without severe acute respiratory syndrome coronavirus 2 (SARS-CoV-2): a systematic review and meta-analysis. Obstet Gynecol 2021, 137:585-596

6. Di Toro F, Gjoka M, Di Lorenzo G, De Santo D, De Seta F, Maso G, Risso FM, Romano F, Wiesenfeld U, Levi-D’Ancona R, Ronfani L, Ricci G: Impact of COVID-19 on maternal and neonatal outcomes: a systematic review and meta-analysis. Clin Microbiol Infect 2021, 27: $36-46$

7. Kotlyar AM, Grechukhina O, Chen A, Popkhadze S, Grimshaw A, Tal O, Taylor HS, Tal R: Vertical transmission of coronavirus disease 2019: a systematic review and meta-analysis. Am J Obstet Gynecol 2021, 224:35-53.e3

8. Smithgall MC, Liu-Jarin X, Hamele-Bena D, Cimic A, Mourad M, Debelenko L, Chen X: Third-trimester placentas of severe acute respiratory syndrome coronavirus 2 (SARS-CoV-2)-positive women: histomorphology, including viral immunohistochemistry and in-situ hybridization. Histopathology 2020, 77:994-999

9. Levitan D, London V, McLaren RA, Mann JD, Cheng K, Silver M, Balhotra KS, McCalla S, Loukeris K: Histologic and immunohistochemical evaluation of 65 placentas from women with polymerase chain reaction-proven severe acute respiratory syndrome coronavirus 2 (SARS-CoV-2) infection. Arch Pathol Lab Med 2021, 145 648-656 
10. Tolu LB, Ezeh A, Feyissa GT: Vertical transmission of severe acute respiratory syndrome coronavirus 2: a scoping review. PLoS One 2021, 16:e250196

11. Facchetti F, Bugatti M, Drera E, Tripodo C, Sartori E, Cancila V, Papaccio M, Castellani R, Casola S, Boniotti MB, Cavadini P, Lavazza A: SARS-CoV2 vertical transmission with adverse effects on the newborn revealed through integrated immunohistochemical, electron microscopy and molecular analyses of placenta. EBioMedicine 2020, 59:102951

12. Raschetti R, Vivanti AJ, Vauloup-Fellous C, Loi B, Benachi A, De Luca D: Synthesis and systematic review of reported neonatal SARSCoV-2 infections. Nat Commun 2020, 11:5164

13. Vivanti AJ, Vauloup-Fellous C, Prevot S, Zupan V, Suffee C, Do Cao J, Benachi A, De Luca D: Transplacental transmission of SARSCoV-2 infection. Nat Commun 2020, 11:3572

14. Bwire GM, Majigo MV, Njiro BJ, Mawazo A: Detection profile of SARS-CoV-2 using RT-PCR in different types of clinical specimens: a systematic review and meta-analysis. J Med Virol 2021, 93: 719-725

15. Colson A, Sonveaux P, Debieve F, Sferruzzi-Perri AN: Adaptations of the human placenta to hypoxia: opportunities for interventions in fetal growth restriction. Hum Reprod Update 2021, 27:531-569

16. Kadam SB, Sukhramani GS, Bishnoi P, Pable AA, Barvkar VT: SARS-CoV-2, the pandemic coronavirus: molecular and structural insights. J Basic Microbiol 2021, 61:180-202

17. Hoffmann M, Kleine-Weber H, Schroeder S, Kruger N, Herrler T, Erichsen S, Schiergens TS, Herrler G, Wu NH, Nitsche A, Muller MA, Drosten C, Pohlmann S: SARS-CoV-2 cell entry depends on ACE2 and TMPRSS2 and is blocked by a clinically proven protease inhibitor. Cell 2020, 181:271-280.e8

18. Ashary N, Bhide A, Chakraborty P, Colaco S, Mishra A, Chhabria K, Jolly MK, Modi D: Single-cell RNA-seq identifies cell subsets in human placenta that highly expresses factors driving pathogenesis of SARS-CoV-2. Front Cell Dev Biol 2020, 8:783

19. Taglauer E, Benarroch Y, Rop K, Barnett E, Sabharwal V, Yarrington C, Wachman EM: Consistent localization of SARS-CoV2 spike glycoprotein and ACE2 over TMPRSS2 predominance in placental villi of 15 COVID-19 positive maternal-fetal dyads. Placenta 2020, 100:69-74

20. Pique-Regi R, Romero R, Tarca AL, Luca F, Xu Y, Alazizi A, Leng Y, Hsu CD, Gomez-Lopez N: Does the human placenta express the canonical cell entry mediators for SARS-CoV-2? Elife 2020, 9: e58716

21. Corman VM, Landt O, Kaiser M, Molenkamp R, Meijer A, Chu DK, Bleicker T, Brunink S, Schneider J, Schmidt ML, Mulders DG, Haagmans BL, van der Veer B, van den Brink S, Wijsman L, Goderski G, Romette JL, Ellis J, Zambon M, Peiris M, Goossens H, Reusken C, Koopmans MP, Drosten C: Detection of 2019 novel coronavirus (2019-nCoV) by real-time RT-PCR. Euro Surveill 2020, 25:2000045

22. Liu J, Babka AM, Kearney BJ, Radoshitzky SR, Kuhn JH, Zeng X: Molecular detection of SARS-CoV-2 in formalin-fixed, paraffinembedded specimens. JCI Insight 2020, 5:e139042

23. Colson A, Depoix CL, Baldin P, Hubinont C, Sonveaux P, Debieve F: Hypoxia-inducible factor 2 alpha impairs human cytotrophoblast syncytialization: new insights into placental dysfunction and fetal growth restriction. FASEB J 2020, 34:15222-15235

24. Edie S, Zaghloul NA, Leitch CC, Klinedinst DK, Lebron J, Thole JF, McCallion AS, Katsanis N, Reeves RH: Survey of human chromosome 21 gene expression effects on early development in Danio rerio. G3 (Bethesda) 2018, 8:2215-2223

25. Pfaffl MW: A new mathematical model for relative quantification in real-time RT-PCR. Nucleic Acids Res 2001, 29:e45

26. Depoix CL, Colson A, Hubinont C, Debieve F: Impaired vascular endothelial growth factor expression and secretion during in vitro differentiation of human primary term cytotrophoblasts. Angiogenesis 2020, 23:221-230
27. Mizuiri S, Hemmi H, Arita M, Ohashi Y, Tanaka Y, Miyagi M, Sakai K, Ishikawa Y, Shibuya K, Hase H, Aikawa A: Expression of ACE and ACE2 in individuals with diabetic kidney disease and healthy controls. Am J Kidney Dis 2008, 51:613-623

28. Ko CJ, Huang CC, Lin HY, Juan CP, Lan SW, Shyu HY, Wu SR, Hsiao PW, Huang HP, Shun CT, Lee MS: Androgen-induced TMPRSS2 activates matriptase and promotes extracellular matrix degradation, prostate cancer cell invasion, tumor growth, and metastasis. Cancer Res 2015, 75:2949-2960

29. Piersigilli F, Carkeek K, Hocq C, van Grambezen B, Hubinont C, Chatzis O, Van der Linden D, Danhaive O: COVID-19 in a 26-week preterm neonate. Lancet Child Adolesc Health 2020, 4:476-478

30. Khong TY, Mooney EE, Ariel I, Balmus NC, Boyd TK, Brundler MA, Derricott H, Evans MJ, Faye-Petersen OM, Gillan JE, Heazell AE, Heller DS, Jacques SM, Keating S, Kelehan P, Maes A, McKay EM, Morgan TK, Nikkels PG, Parks WT, Redline RW, Scheimberg I, Schoots MH, Sebire NJ, Timmer A, Turowski G, van der Voorn JP, van Lijnschoten I, Gordijn SJ: Sampling and definitions of placental lesions: Amsterdam Placental Workshop Group Consensus Statement. Arch Pathol Lab Med 2016, 140:698-713

31. Kliman HJ, Nestler JE, Sermasi E, Sanger JM, Strauss JF 3rd: Purification, characterization, and in vitro differentiation of cytotrophoblasts from human term placentae. Endocrinology 1986, 118: $1567-1582$

32. Ogando NS, Dalebout TJ, Zevenhoven-Dobbe JC, Limpens R, van der Meer Y, Caly L, Druce J, de Vries JJC, Kikkert M, Barcena M, Sidorov I, Snijder EJ: SARS-coronavirus-2 replication in Vero E6 cells: replication kinetics, rapid adaptation and cytopathology. J Gen Virol 2020, 101:925-940

33. Shah PS, Diambomba Y, Acharya G, Morris SK, Bitnun A: Classification system and case definition for SARS-CoV-2 infection in pregnant women, fetuses, and neonates. Acta Obstet Gynecol Scand 2020, 99:565-568

34. Schwartz DA, Morotti D, Beigi B, Moshfegh F, Zafaranloo N, Patane L: Confirming vertical fetal infection with coronavirus disease 2019: neonatal and pathology criteria for early onset and transplacental transmission of severe acute respiratory syndrome coronavirus 2 from infected pregnant mothers. Arch Pathol Lab Med 2020, $144: 1451-1456$

35. Delfino M, Guida M, Patri A, Spirito L, Gallo L, Fabbrocini G: SARS-CoV-2 possible contamination of genital area: implications for sexual and vertical transmission routes. J Eur Acad Dermatol Venereol 2020, 34:e364-e365

36. von Stillfried S, Boor P: Detection methods for SARS-CoV-2 in tissue. Pathologe 2021:1-8

37. Algarroba GN, Rekawek P, Vahanian SA, Khullar P, Palaia T, Peltier MR, Chavez MR, Vintzileos AM: Visualization of severe acute respiratory syndrome coronavirus 2 invading the human placenta using electron microscopy. Am J Obstet Gynecol 2020, 223: 275-278

38. Hosier H, Farhadian SF, Morotti RA, Deshmukh U, Lu-Culligan A, Campbell KH, et al: SARS-CoV-2 infection of the placenta. J Clin Invest 2020, 130:4947-4953

39. Kniss DA: Alternative interpretation to the findings reported in visualization of severe acute respiratory syndrome coronavirus 2 invading the human placenta using electron microscopy. Am J Obstet Gynecol 2020, 223:785-786

40. Bullock HA, Goldsmith CS, Zaki SR, Martines RB, Miller SE: Difficulties in differentiating coronaviruses from subcellular structures in human tissues by electron microscopy. Emerg Infect Dis 2021, 27: 1023-1031

41. Menter T, Mertz KD, Jiang S, Chen H, Monod C, Tzankov A, Waldvogel S, Schulzke SM, Hosli I, Bruder E: Placental pathology findings during and after SARS-CoV-2 infection: features of villitis and malperfusion. Pathobiology 2021, 88:69-77

42. Schwartz DA, Morotti D: Placental pathology of COVID-19 with and without fetal and neonatal infection: trophoblast necrosis and chronic 
histiocytic intervillositis as risk factors for transplacental transmission of SARS-CoV-2. Viruses 2020, 12:1308

43. Sharps MC, Hayes DJL, Lee S, Zou Z, Brady CA, Almoghrabi Y, Kerby A, Tamber KK, Jones CJ, Adams Waldorf KM, Heazell AEP: A structured review of placental morphology and histopathological lesions associated with SARS-CoV-2 infection. Placenta 2020, 101: $13-29$

44. Ouyang Y, Bagalkot T, Fitzgerald W, Sadovsky E, Chu T, MartinezMarchal A, Brieno-Enriquez M, Su EJ, Margolis L, Sorkin A, Sadovsky Y: Term human placental trophoblasts express SARSCoV-2 entry factors ACE2, TMPRSS2, and Furin. mSphere 2021, 6:e0250-21

45. Mahyuddin AP, Kanneganti A, Wong JJL, Dimri PS, Su LL, Biswas A, Illanes SE, Mattar CNZ, Huang RY, Choolani M: Mechanisms and evidence of vertical transmission of infections in pregnancy including SARS-CoV-2s. Prenat Diagn 2020, 40:1655-1670

46. Bloise E, Zhang J, Nakpu J, Hamada H, Dunk CE, Li S, Imperio GE, Nadeem L, Kibschull M, Lye P, Matthews SG, Lye SJ: Expression of severe acute respiratory syndrome coronavirus 2 cell entry genes, angiotensin-converting enzyme 2 and transmembrane protease serine 2 , in the placenta across gestation and at the maternal-fetal interface in pregnancies complicated by preterm birth or preeclampsia. Am J Obstet Gynecol 2021, 224:298.e1-298.e8

47. Hecht JL, Quade B, Deshpande V, Mino-Kenudson M, Ting DT, Desai N, Dygulska B, Heyman T, Salafia C, Shen D, Bates SV, Roberts DJ: SARS-CoV-2 can infect the placenta and is not associated with specific placental histopathology: a series of 19 placentas from COVID-19-positive mothers. Mod Pathol 2020, 33:2092-2103

48. Clinckemalie L, Spans L, Dubois V, Laurent M, Helsen C, Joniau S, Claessens F: Androgen regulation of the TMPRSS2 gene and the effect of a SNP in an androgen response element. Mol Endocrinol 2013, 27:2028-2040

49. Qiao Y, Wang XM, Mannan R, Pitchiaya S, Zhang Y, Wotring JW, Xiao L, Robinson DR, Wu YM, Tien JC, Cao X, Simko SA, Apel IJ, Bawa P, Kregel S, Narayanan SP, Raskind G, Ellison SJ, Parolia A, Zelenka-Wang S, McMurry L, Su F, Wang R, Cheng Y, Delekta AD, Mei Z, Pretto CD, Wang S, Mehra R, Sexton JZ, Chinnaiyan AM: Targeting transcriptional regulation of SARS-CoV-2 entry factors ACE2 and TMPRSS2. Proc Natl Acad Sci U S A 2020, 118. e2021450118
50. Louw-du Toit R, Perkins MS, Hapgood JP, Africander D: Comparing the androgenic and estrogenic properties of progestins used in contraception and hormone therapy. Biochem Biophys Res Commun 2017, 491:140-146

51. Zang R, Gomez Castro MF, McCune BT, Zeng Q, Rothlauf PW, Sonnek NM, Liu Z, Brulois KF, Wang X, Greenberg HB, Diamond MS, Ciorba MA, Whelan SPJ, Ding S: TMPRSS2 and TMPRSS4 promote SARS-CoV-2 infection of human small intestinal enterocytes. Sci Immunol 2020, 5:eabc3582

52. Matsuyama S, Nao N, Shirato K, Kawase M, Saito S, Takayama I, Nagata N, Sekizuka T, Katoh H, Kato F, Sakata M, Tahara M, Kutsuna S, Ohmagari N, Kuroda M, Suzuki T, Kageyama T, Takeda M: Enhanced isolation of SARS-CoV-2 by TMPRSS2expressing cells. Proc Natl Acad Sci U S A 2020, 117:7001-7003

53. Shang J, Wan Y, Luo C, Ye G, Geng Q, Auerbach A, Li F: Cell entry mechanisms of SARS-CoV-2. Proc Natl Acad Sci U S A 2020, 117 : $11727-11734$

54. Wei J, Alfajaro MM, DeWeirdt PC, Hanna RE, Lu-Culligan WJ, Cai WL, Strine MS, Zhang SM, Graziano VR, Schmitz CO, Chen JS, Mankowski MC, Filler RB, Ravindra NG, Gasque V, de Miguel FJ, Patil A, Chen H, Oguntuyo KY, Abriola L, Surovtseva YV, Orchard RC, Lee B, Lindenbach BD, Politi K, van Dijk D, Kadoch C, Simon MD, Yan Q, Doench JG, Wilen CB: Genome-wide CRISPR screens reveal host factors critical for SARS-CoV-2 infection. Cell 2021, 184:76-91.e13

55. Cantuti-Castelvetri L, Ojha R, Pedro LD, Djannatian M, Franz J, Kuivanen S, van der Meer F, Kallio K, Kaya T, Anastasina M, Smura T, Levanov L, Szirovicza L, Tobi A, Kallio-Kokko H, Osterlund P, Joensuu M, Meunier FA, Butcher SJ, Winkler MS, Mollenhauer B, Helenius A, Gokce O, Teesalu T, Hepojoki J, Vapalahti O, Stadelmann C, Balistreri G, Simons M: Neuropilin-1 facilitates SARS-CoV-2 cell entry and infectivity. Science 2020, 370: $856-860$

56. Kreis NN, Ritter A, Louwen F, Yuan J: A message from the human placenta: structural and immunomodulatory defense against SARSCoV-2. Cells 2020, 9:1777

57. Celik O, Saglam A, Baysal B, Derwig IE, Celik N, Ak M, Aslan SN, Ulas M, Ersahin A, Tayyar AT, Duran B, Aydin S: Factors preventing materno-fetal transmission of SARS-CoV-2. Placenta 2020, 97:1-5 